11. Панкєєв С.В. Продуктивність сортів пшениці озимої залежно від фону живлення та умов зволоження на Півдні України: дис. ... канд. с.-г. наук: 06.01.09. ДВНЗ «Херсонський державний аграрний університет». Херсон, 2017. С. 26.

12. Васильківський С.П., Кочмарський В.С. Селекція і насінництво польових культур: підручник. ПрАТ «Миронівська друкарня», 2016. С. 58.

13. Сщенко В.О, Копитко П.Г., Опришко В.П., Костогриз П.В. Основи наукових досліджень в агрономії: підручник. Київ : Дія, 2005. 288 с.

14. Ушкаренко В.О. та ін. Дисперсійний і кореляційний аналіз у землеробстві та рослинництві. Навч. посіб. Херсон : Айлант, 2008. 272 с.

UDC 58; 581.1

DOI https://doi.org/10.32851/2226-0099.2021.122.3

\title{
SPECIES INCLUDED IN THE GENUS SORBUS L. WHICH SPREAD IN THE FLORA OF THE NAKHCHIVAN AUTONOMOUS REPUBLIC
}

\author{
Gulamova A. - PhD Student, Head Laboratory Assistant of the Department of Economics, \\ Nakhchivan University
}

Sorbus L. genus is a forest plant belonging to the Moloideae subfamily of the Rosaceae family. Genus Sorbus L. which is economically valuable, is suitable for the Nakhchivan climate and is distributed in high mountainous areas. Recently, we have obtained new information by conducting research on species belonging to the genus Sorbus L. These studies were carried out in the direction of a collection of species included in the genus Sorbus L., determination of their species composition, identification of endangered species, analysis of the systematic composition, determination of botanical-geographical characteristics and calculation of natural resources. According to the literature material, 17 species (Sorbus aucuparia L., S. boisseri Schneid. S. graeca (Spach) Lood. Ex Schauer (Sorbus baldacii Degen et Fritsch ex Schneid), S. luristanica (Bornm.) Schönbeck-Temesy, Sorbus persica Hedl., Sorbus roopiana Bordz., Sorbus subfusca (Ledeb.) Boiss., Sorbus takhtajanii Gabr., Sorbus turcica Zinserl. (Sorbus umbellata (Desf) Fritsch), Sorbus albovii Zinserl., Sorbus armeniaca Hedl., Sorbus buschiana Zinserl., Sorbus caucasica Zinserl., Sorbus fedorovii Zaikonn., Sorbus kusnetzovii Zinserl., Sorbus migarica Zinserl., Sorbus tamamschjanae Gabr.) of Sorbus L. are distributed in the flora of the Nakhchivan Autonomous Republic. All species of the genus Sorbus L. are found in groups, sometimes individually in the upper, middle and, to a lesser extent, in the lower mountain ranges or in sparse forests. Rowan forms Sorbueta formations and phytocenoses. It plays a role as a subdominant in phytocenoses. In height, it lags behind some trees and shrubs and inhabits the second and third tiers. Species of the genus Sorbus L. are valuable medicinal, decorative, as well as plants that produce nectar and pollen. All shaped species of the genus Sorbus L. (trees and shrubs) reduce soil erosion and increase soil fertility.

Key words: Sorbus L., genus, systematic analysis, botanical description, bioecological features.

Гуламова А. Вид роду Sorbus l., щео поширився у флорі Нахічеванської автономної республіки

Рослини роду Sorbus L. - иее лісові рослини, щзо належить до підродини Moloideae, родини Rosaceae. Pid Sorbus L., який є економічно иінним, підходить для клімату Нахічевані та поширений у високогірних районах. Нещздавно ми отримали нову інформацію, здійснивши дослідження видів, які належать до роду Sorbus L. Досліджено колекцію видів роду Sorbus L.; визначено види, що зникають; здійснено аналіз системного складу; наведено ботаніко-географічну характеристику і розрахунок природних ресурсів. За матеріалами наукової літератури, 17 видів (Sorbus aucuparia L., S. boisseri Schneid. S. graeca (Spach) Lood. Ex Schauer (Sorbus baldacii Degen et Fritsch ex Schneid), S. luristanica (Bornm.) 
Schönbeck-Temesy, Sorbus persica Hedl., Sorbus roopiana Bordz., Sorbus subfusca (Ledeb.) Boiss., Sorbus tahtajanii Gabr., Sorbus turcica Zinserl. (Sorbus umbellata (Desf) Fritsch), Sorbus albovii Zinserl., Sorbus Sorbus Zinserl., Hedinbus Zinserl.., Sorbus caucasica Zinserl., Sorbus fedorovii Zaikonn., Sorbus kusnetzovii Zinserl., Sorbus migarica Zinserl., Sorbus tamamschjanae Gabr.) роду Sorbus L. поширені у флорі Нахічеванської Автономної Республіки. Усі види роду Sorbus L. зустрічаються групами, іноді поодиноко у верхніх, середніх $i$, меншою мірою, у нижніх гірських хребтах або у рідколіссях. Горобина створює сорбуетні формачії та фітоценози, а також відіграє роль субдомінанта у фітоценозах. За висотою рослин горобина відстає від деяких дерев і чагарників та заселяє другий і третій яруси. Види роду Sorbus L. представлені цінними лікарськими і декоративними рослинами, а також рослинами, що виробляють нектар і пилок. Усі види роду Sorbus L. рослинних формацій (дерева i чагарники) зменшують ерозію трунту і підвищують його родючість.

Ключові слова: Sorbus L., pid, систематичний аналіз, ботанічний опис, біоекологічні особливості.

Formulation of the problem. Sorbus L. plant is of great importance in domestic, medical, industrial and construction fields. The study of aspects of plants that are beneficial, both biologically and technically, is relevant to many fields of science.

Analysis of recent research and publications. For the first time information on the prevalence of the genus Sorbus L. was given by Linney and and Linney has identified 2 species of the genus Sorbus L.: Sorbus aucuparia L. and Sorbus domestica. After L. Linney, A.P.de Candolle in 1825, F. Unger in 1869, J.I. Maximovitz in 1874, E. Koehne in 1890-1891, J.T. Hedlund in 1901, C.K. Schneider in 1906, A. Rehder in 1949, A.A. Grossgeim in 1952, A.V. Gursky in 1957, Z. Karpati in 1960, M. Kovanda in 1961-1965, C. Weber in 1964, T.T. Yu in 1974, E.T. Gabrielyan in 1978, J.B. Phipps in 1990, K.R. Robertson in 1991, H. McAllister in 2005, J.D. Postman in 2011 and others studied species belonging to the genus Sorbus L. and gave general information about them.

The genus Sorbus L. is a forest plant belonging to the family Rosaceae, and the number of species has been shown differently in different literatures. It was given by Komarov, Zinserling in 1939, Simpson in 1957 and Alekseev in 1997, which includes 80 species of the genus Sorbus L. Gabrielyan in 1978, Lun Lingdi and Spongberg in 2003 identified 100 species belonging to the genus. In 1996, Nedoluzhko, in 2002, Koropachinsky and Vstovskaya reported that 70 species belonging to the genus Sorbus L. Aldasoro in 1998, Phipps in 1990 identified 250 species belonging to the genus Sorbus L. [1, 2014].

The genus Sorbus L is widespread in Europe, the Caucasus, Western Asia and the Northern Hemisphere [16, 2001]. The genus Sorbus L. is a plant species belonging to the Maloideae subfamily of the Rosaceae family, which occurs in the northern hemisphere According to the latest classifications (Phipps, Smith, 1990; Aldasoro, 2004; McAllister, 2005), 250-300 species of trees and shrubs are included in the genus Sorbus L. The genus Sorbus L. has been classified into subgenuses by Robertson, McAllister, Campbell, Potter and other scientists. This classification was carried out mainly due to the structure of the leaves.

According to the latest classification, the genus Sorbus L. is divided into 6 subgenuses: Sorbus, Aria, Mikromeles, Cormus, Torminaria, Chamaemespilus. The Sorbus subgenus includes species with hairless or finely hairy leaves. For example: $S$. aucuparia L., S. boisseri Schneid., S. subfusca (Ledeb.) another subspecies of the genus Sorbus L., Aria, is distinguished by its simple leaves and white hairs on the underside of the leaf. This subgenus includes the types of S. graeca (Spach) Lood. Ex Schauer (S. baldacii Degen et Fritsch ex Schneid), S. luristanica (Bornm.) Schönbeck-Temesy, S. persica Hedl., S. takhtajanii Gabr., S. armeniaca Hedl., S. caucasica Zinserl., S. tamamschjanae 
Gabr. Micromeles are taken as another subgenus. However, this subgenus is mostly attributed to the subgenus Aria. The leaves of the subgenus Cormus are similar in structure to the Sorbus subgenus. However, they differ in the structure of their fruits. The subgenus Cormus includes the species Sorbus domestica. Sorbus torminalis species is being belonged to the subgenus Torminaria. The other subspecies that includes the Sorbus chamaemespilus species is the Chamaemespilus. In addition to these subgenuses, the genus Sorbus L. has been divided into hybrid and polyploid taxa [1, 2014]. Small species of the genus Sorbus L. are more common in Europe, but spread over a small area. The most common species are plants belonging to the genus Sorbus Aria. These species are found in abundance in the British Isles, Germany, Slovakia and Hungary. In general, the genus Sorbus is divided into three subgenus due to its distribution in Asia, Europe and North America: Sorbus, Aria, Chamaemespilus. Based on our research, it was determined that 17 species of the genus Sorbus L. are widespread in the Nakhchivan Autonomous Republic. For the first time, A.A. Grossgeim provided information about the species belonging to the genus Sorbus L. [5, 1936] which are distributed in the flora of the Nakhchivan Autonomous Republic, and is shown in the second volume of the book "Flora of Azerbaijan". Later, in the work of L.I. Prilipko "Растительное отнощения в Нахичеванской АССР" $[14,1939]$ information was given about a species of the genus Sorbus L. distributed in the Nakhchivan AR. In the following years, A.A. Grossgeim's book "Flora Kafkaza" $[6,1952]$ provided information about four species of the genus Sorbus L. distributed in the territory of Nakhchivan AR. "Флора Азербайджана" [3, 1954], "Trees and shrubs of Azerbaijan" [20, 1970] and M.S. Mammadov, K.S. Asadov and F.M. Mammadov's book "Dendrology" [13, 2000] provides information about 4 species of the genus Sorbus L. distributed in the flora of the Nakhchivan Autonomous Republic.

Scientific innovation. The article identifies the types of Sorbus L plants that are new to the flora of the Nakhchivan Autonomous Republic. The research also includes information on species synonyms, distribution patterns in altitude zones, biotope, flowering and fruit ripening periods. According to the notes in the book of E.T. Gabrielyan, $[4,1978] 6$ species of the genus Sorbus L. are distributed in the territory of the Nakhchivan Autonomous Republic. A.Sh. Ibrahimov [10, 2005] informed about the distribution of S. graeca (Spach) Lodd. ex Schauer, S. boissieri C.K. Schneid., S. persica Hedl. species in the territory of the Nakhchivan Autonomous Republic on the basis of his researches. A.M. Asgarov [2, 2006] also gave information about the species belonging to the genus Sorbus L. distributed in the territory of the Autonomous Republic, and thus it was shown that 12 species of Sorbus distributed in the flora of Azerbaijan. In T.H. Talibov's [16, 2001] researches in the area S.aucuparia L., S. boissieri C.K. Schneid., $S$. graeca (Spach) Lodd. ex Schauer, S. persica Hedl. species have been reported to be widespread. In the following years, based on research and literature Anvar Ibrahimov wrote an article titled "Systematic analysis and distribution zones of Sorbus L. species distributed in the flora of Nakhchivan Autonomous Republic" and noted that 9 species of Sorbus L. were distributed in Nakhchivan AR. [11, 2008]. In the scientific work of T.H. Talibov and A.M. Ibrahimov [11, 2008] "New species of Sorbus L. for the flora of the Nakhchivan Autonomous Republic" information was given about 8 more species belonging to the genus Sorbus L., new to the flora of the Nakhchivan Autonomous Republic. The latest research work by A. Gulamova and H. Seyidova entitled "Study status of the genus Sorbus L. in the flora of the Nakhchivan Autonomous Republic" notes that 17 species of the genus Sorbus L. are widespread in the territory of the Nakhchivan Autonomous Republic [15, 2019]. 
Purpose of the article. The purpose of writing this article is to study the regularities of the distribution of plants grown in Nakhchivan, as well as the analysis of materials collected during many years of research, including scientific expeditions and the study of literary data.

Discussion of the research. The genus Sorbus L. has recently been studied in the Nakhchivan Autonomous Republic and research is currently underway. As a result of the research, it was determined that 17 species (Sorbus aucuparia L., S. boisseri Schneid. S. graeca (Spach) Lood. Ex Schauer (Sorbus baldacii Degen et Fritsch ex Schneid), S. luristanica (Bornm.) Schönbeck-Temesy, Sorbus persica Hedl., Sorbus roopiana Bordz., Sorbus subfusca (Ledeb.) Boiss., Sorbus takhtajanii Gabr., Sorbus turcica Zinserl. (Sorbus umbellata (Desf) Fritsch), Sorbus albovii Zinserl., Sorbus armeniaca Hedl., Sorbus buschiana Zinserl., Sorbus caucasica Zinserl., Sorbus fedorovii Zaikonn., Sorbus kusnetzovii Zinserl., Sorbus migarica Zinserl., Sorbus tamamschjanae Gabr.) belonging to the genus Sorbus L. are distributed in the flora of the Nakhchivan Autonomous Republic. [15, 2019]

Species belonging to the genus Sorbus L. are shrubs or trees with a strong root system, reaching a height from $3 \mathrm{~m}$ to $25 \mathrm{~m}$. It grows mainly in mountainous and rocky places, sometimes rarely among meadows and forests of different composition (12, p. 108-111). It is a fast growing tree and grows up to $0.5 \mathrm{~m}$ per year. Species of this genus give a good crop every 3 years. However, it gives the best quality product after 30-40 years. The yield of one tree can be $80-100 \mathrm{~kg}$. The life span of the species belonging to the genus Sorbus L. is 100-150 years, sometimes 200 years. The leaves are simple and complex with a group of It has a group of multi-flowered thyroid flowers. The flowers are white or pink and rich in nectar. Honey obtained from rowan flowers has a beautiful red color and a strong aroma. The fruits are berries and are white, yellow, red and black. The fruits are rich in biologically active substances. These are sugar (glucose, fructose, sucrose), sorbitol, organic acids, vitamins C, P, K1, E, B (B2, B9), provitamin $\mathrm{A}$; amygdalin, macro and microelements (Fe, $\mathrm{Mn}, \mathrm{Cu}, \mathrm{Zn}, \mathrm{Ni}, \mathrm{Cr}, \mathrm{Co}, \mathrm{Mo}$, $\mathrm{Ca}, \mathrm{K}, \mathrm{P})$ and other substances. The number of fruit leaves varies from 2 to 5 . Partial merging of fruit leaves with a receptacle occurs only in the rule part. In the ovary, there are two ovules, one of which is fertilized and transformed into seed. It blooms in MayJune and matures in September-October. If the fruit is not eaten by birds, it remains on the tree until winter $[13,2000]$.

Sorbus aucuparia L. is $5-15 \mathrm{~m}$, sometimes $4-20 \mathrm{~m}$ high. The young stem is gray, straight and smooth. The bark of older species cracks and gradually darkens in color. The length of the apex shoots is $8-15 \mathrm{~cm}$ and has a rectangular-conical structure. The colour of the scales is dark brown. The surface is hairy, often surrounded by leaf blades. The lateral shoots are located in the leaf axils and are relatively small and sparsely hairy. The reddish-brown petioles are 1.5-6.7 cm long. The surface of the petiole is sparsely hairy or completely bare. Leaves are compound, feather-like, consisting of 11-17 petals. The leaves are pointed and have a serrated edge. The upper part of the leaves is hairy, dark green, and the lower part is light green. The leaves reach a length of $10-20 \mathrm{~cm}$. The white flowers are $1 \mathrm{~cm}$ in diameter. The petals are densely hairy and $5 \mathrm{~mm}$ in diameter. The calyx, which consists of 5 calyx leaves, becomes hairy, then becomes bare. The style of the pistil is $2-5 \mathrm{~cm}$, leaf pedicel is hairy. The number of stamens is 20 . It has a It has a group of multi-flowered thyroid flower group.

Sorbus aucuparia L. begins to bloom in May and lasts 10-15 days. The fruits are reddish-orange in color and spherical in shape. The diameter is about $1 \mathrm{~cm}$. The fruit is a berry, ripening in August-September. The fruits contain organic acids and vitamins, 
and the bark of the stem contains up to $7 \%$ of vaccines, so it has long been used as a fruit and medicinal plant. Sorbus aucuparia L. propagates vegetatively by root shoots and elongated shoots [9, 2021]. Naturally, it is widespread in Europe, the Caucasus and Siberia. In the Nakhchivan Autonomous Republic, it is distributed in the forests around Bichanak village of Shahbuz district and Nurgut village of Ordubad district.

S. Boisseri Schneid. It looks like a Caucasian Sorbus. It is somewhat difficult to distinguish them. It differs from it only by the presence of smell of buds. The surface of the fragrant shoots is covered with glandular hairs. The leaf consists of 11-15 petals. The leaves are broad, elliptical, lance-shaped. The width is more than $2 \mathrm{~cm}$. The fruit is red or orange-red, round-ovate, $8-11 \mathrm{~mm}$ in diameter. Blooming occurs in May-July. The fruit ripens in September. Widespread in the Caucasus and Asia Minor. It is spread in the flora of Nakhchivan Autonomous Republic in the forests around Bichanak village of Shahbuz district and Nurgut village of Ordubad district.

$S$. graeca (Spach) Lood. Ex Schauer is a tree 3-4 $\mathrm{m}$ high, sometimes up to $7 \mathrm{~m}$. It is usually found in groups, sometimes individually, in meadows, around rocks, and in forests. The color of young shoots is brown, the color of the bark of old stems is gray. The leaves are simple, broad, oblong elliptic, smooth on the upper part, dark green, grayish and hairy on the underside. The edges of the leaves are double-toothed. Vegetation occurs from late April to October. White blooms in June. The spherical fruits are red and ripen in August. The fruit is hairy and turns green when fully ripe. Propagated by seeds and grafting. It is a light-loving mesophyte. It is winter resistant. It is suitable for use in gardening, landscaping, as a decorative plant. The stem is solid and elastic. From the leaves are produced paint of different colors. Besides being a decorative plant, it is also a honey plant $[8,2019]$. Naturally grows in Southern Europe, Crimea, Caucasus, Asia Minor. In the territory of Nakhchivan Autonomous Republic it is spread in Bichanak forest of Shahbuz district and around Batabat lake, Tillak, Ashagi and Yukhari Jalil forests around Nurgut village of Ordubad district, forests and bushes between Nasirvaz village and Garangush plateau.

S. luristanica (Bornm.) Schönbeck-Temesy is a tree or shrub up to 5-6 $\mathrm{m}$ in height, sometimes up to $10 \mathrm{~m}$. The colour of the bark of the stem is reddish-yellow. Young reddish-brown shoots are bare. The shoots are 3-6 mm long and covered with yellowish-brown hairy scales. It has narrow inverted ovate leaves with short pointed tips. The upper part of the leaves is light green, the lower part is velvety or felt-like hairy, gray. It has a little hairy petiole. The flowers are of medium size and have a group of flowers with 25-40 flowers on them. The flowers are yellowish or white. The fruits are large and oval, 20-35 $\mathrm{mm}$ in diameter. The color of the fruit is reddish-yellow or red. It blooms in May-June and bears fruit in September. Propagated generatively. In general, it is widespread in the south of the Caucasus, Iran and Turkey. In the Nakhchivan Autonomous Republic, it is spread around Bichanak forest and Batabat lake of Shahbuz district.

S. persica Hedl is a small tree species found in the mountainous areas of the Nakhchivan Autonomous Republic at an altitude of 2100-2500 m above sea level. Its height is about 3-7 m, sometimes up to $10 \mathrm{~m}$. The branches are light brown. The edges of the leaves are elliptical or oblong, serrated. The leaves are up to $7 \mathrm{~cm}$ long and $6 \mathrm{~cm}$ wide. The blooming period covers May-June and has a multi-flowered cluster of flowers. The petals are white. The color of the fruit is usually orange-red. The fruit is oval in shape and ripens in September-October. As the fruit matures, it changes color and becomes whitish. The fruit is cold-resistant and sometimes stays on the trees until frost. Reproduction occurs by seed. Sometimes they use grafting. The vegetation period is long, usually 164 days. In general, it is widespread in Russia, Turkey, Iran and Azerbaijan. 
In the Nakhchivan Autonomous Republic, it is spread in the surrounding forests of Bichanak and Kuku villages of Shahbuz district and in the territory of Khazinadara of Julfa district.

S. roopiana Bordz. is a small tree or shrub up to 4-10 meters with a pyramidal top. The bark of the stem of young trees is bright red and straight. Apex shoots are larger than side shoots and are 6-9 $\mathrm{mm}$ long. The leaf petiole is yellowish green between $1.1-3.1 \mathrm{~cm}$ long and covered with cotton-like hairs. The underside of the leaf consists of 1-3 (4) individual petals, and the upper part is a deep mass or with deep teeth up to the middle vein. The underside of the leaf is green and covered with gray hairs. Then these hairs are shed. The surface of the leaf is dark green and bare. The group of flowers in the form of a standing false umbrella is $9 \mathrm{~cm}$ long and 7-10 cm wide. The off-white flowers are 12-14 mm tall and have long hairs at the base of the petals. The fruits, which turn dark red when ripe, are spherical-elliptical in shape. These fruits, which are $10 \mathrm{~mm}$ in diameter, contain 3-5 seeds. It is more common in Turkey [21, 2018]. It is spread in Bichanak forest of Shahbuz district in our Autonomous Republic.

S. subfusca (Ledeb.) Boiss. is found in beech forests, rocky areas and forest edges in the upper and middle mountain ranges at altitudes up to $2000 \mathrm{~m}$ above sea level. It is not very widespread in Azerbaijan. It is a tree or shrub up to 8-10 $\mathrm{m}$ high in its natural area. The leaves are large, $7-11 \mathrm{~cm}$ long. The edges are double, sometimes with deep teeth. The tip is pointed, it is usually round or wedge-shaped towards the leaf blade, ovoid or elliptical. The upper part of the leaf is dark green, and the lower part is yellowish-green, covered with white hairs. The leaf petiole is $0.5-2.0 \mathrm{~cm}$ long. The calyx is felt-like hairy and has the blunt gear. The flowers are white, broadly elliptical. The fruit is spherical, first dark red, then dark blue, covered with dots. It reproduces generatively in nature. It is common in the Caucasus and Turkey. In our Autonomous Republic it is spread around Kuku village of Shahbuz district.

S. takhtajanii Gabr. are 3-6 m tall, forest shrubs spread in high mountains. The color of the bark of the stem is reddish-gray. The shoots are 3-6 mm in size and covered with 3-4 scales. Rhombic-elliptical leaves are 4.5-7 cm long. The upper part of the leaf is dark green and bare, and the lower part is covered with white hairs. The length of the leaf petiole is $0.7-2 \mathrm{~cm}$. The group of flowers is in the form of a false umbrella and consists of 25-30 flowers. The color of the fruits is orange-yellow or yellowish-red. Spherical fruits have 2-4 seeds. In general, it is widespread in Azerbaijan and Turkey. It is spread in the territory of Nakhchivan Autonomous Republic in Bichanak forest of Shahbuz district and in the foothills of Sarvarti mountain.

S. turcica Zinserl. (S.umbellata (Desf) Fritsch) is a medium-sized tree or shrub plant. The shoots are slightly hairy. The part of the leaves close to the petiole is rounded or wide, and the tip is blunt. The leaves are $4-6 \mathrm{~cm}$ wide and $5-7 \mathrm{~cm}$ long. The lateral veins are 6-8 pairs. The top is bare, and the bottom has densely felt-like hairy. The number of teeth on the edge of the leaf is $10-20$. The petiole is $5-1.5 \mathrm{~cm}$ long. The pointed, egg-shaped shoots are covered with 3-4 scales and are less sticky. The pedicel, receptacle and ripe fruits are white and have felt-like hair. The gears of the receptacle are triangular. The fruits are globular dark red and have 3-4 seeds. It blooms in May and bears fruit in August-September. In general, it is spread in Crimea, in the north of the Caucasus, in Turkey [21, 2018]. In our Autonomous Republic it is spread in Bichanak, Ayrinj, Kuku of Shahbuz district, Nurgut, Urmus, Mazra villages of Ordubad district and Sadarak district.

S. albovii Zinserl. is a tree or shrub that grows between beech and pine forests in the subalpine zone at an altitude of 1800-2000 m above sea level. There are few hairy or 
bare shoots. Inverted oval or elliptical leaves are usually less narrowed or rounded from the petiole. It is usually pointed, 7-10 cm long and 4-7 cm wide. It has $8-11$ pairs of lateral veins. The upper part of the leaf is bare (initially less hairy along the veins), and the lower side is green and weakly hairy. Its margins are serrated, the upper side is usually double- serrated, the sharp teeth reaching up to the blade of the leaf. The receptacle is felt-like hairy and the teeth are triangular. The petals are ovate. The fruits are round or oval, red, and when fully ripe, they turn green. It blooms in May-June and bears fruit in August-September. Naturally, it is common in the Caucasus. It is spread in the forests around Bichanak village of Shahbuz district and Nurgut village of Ordubad district in the territory of Nakhchivan Autonomous Republic.

S. armeniaca Hedl. is a shrub or low tree that grows in rocky places at an altitude of 1500-2300 $\mathrm{m}$ above sea level along the upper border of the forest. The ovate, elliptical or elongated elliptical leaves are deepened in the part that is close to the petiole. The tip of the leaf is pointed or slightly obtuse, $6-8 \mathrm{~cm}$ long, $3.5-5 \mathrm{~cm}$ wide, with $5-7$ shallow slices (the lower slices reach 1/2-1 / 3 of the width of the leaf blade). The number of teeth reaches 30-36. The upper part is dark green and bare, the lower part is greyish or white with dense felt-like hairs. There are 9-10 pairs of lateral veins on the leaf, and they are clearly visible under the leaf. It has a group of multi-flowered flowers. The edges of the receptacle are in the shape of a pointed triangle. The petals are white and ovate in shape. The fruits are 1.0-1.2 cm long and $0.8-1.1 \mathrm{~cm}$ wide, oval or round. Ripe fruits are red and turn green when dried. It blooms in May-June and bears fruit in SeptemberOctober. Naturally distributed in the Caucasus. In our Autonomous Republic, it is found in the forests around Bichanak village of Shahbuz district and Nurgut village of Ordubad district [19, 2017].

S. buschiana Zinserl. is a low tree or shrub reaching 4-6 $\mathrm{m}$ in height, growing in sparse forests at an altitude of 1850-2200 m above sea level. The leaves are 10-11 cm long. The leaves are double, broad or ovate-elliptical in the fruit-bearing shoots and scalpel shaped in the fruitless shoots. The number of lateral veins on the leaf is 10-11 pairs, the edges are double-serrated. The lower surface is grey-greenish-feathery. As it goes towards the petiole, it takes the form of a wedge. Naturally, it is widespread in the Caucasus. In the flora of our Autonomous Republic, it is spread in the forests around Bichanak village of Shahbuz district and Nurgut village of Ordubad district.

$S$. caucasica Zinserl. is a broad-topped, low-growing tree or shrub reaching 4-7 $\mathrm{m}$ in height. The bark of the stem is reddish-dark gray and has a smooth surface. The leaves are inverted ovate, round, broadly elliptical, or in some cases elongated elliptical, with a broad wedge-shaped shape close to the petiole. It is blunt or pointed, (8) $10-12(15) \mathrm{cm}$ long and 6-11 cm wide. It has 5-7 slices with not very deep edges (slices reach 1 (3-1) 4 parts of the width of the leaf). The number of pointed teeth reaches 30-35. The leaves are dark green on top and bare, and the underside is densely gray or whitish felt-like hairy. The leaf has 7-9 pairs of lateral veins. As in other species, the veins on the lower surface of the leaf are clearly distinguished and has felt-like hair. The length of the leaf petiole is between $1.2-2.2 \mathrm{~cm}$. It has a group of multi-flowered flowers and bears 40-50 (-70) flowers. The pedicel is felt-like hairy. The petals are white and inverted ovate. The fruits are $1.0-1.4 \mathrm{~cm}$ long and $0.6-1.1 \mathrm{~cm}$ wide. The shape is oval or slightly elongated, the numbers 7-12 (20) are grouped together in It has a group of multi-flowered thyroids. Ripe fruits are red, bare and turn green when dried. 2-3 reddish brown seeds are 5-6 mm long. It blooms in May-June and bears fruit in August-September. It is naturally common in the Eastern and Western Caucasus. It is found in the forests around Bichanak village of Shahbuz district in the flora of Nakhchivan Autonomous Republic. 
S. fedorovii Zaikonn is a shrub growing at an altitude of 1600-2000 m above sea level. Its height is $2 \mathrm{~m}$. The leaves are $7-10 \mathrm{~cm}$ long. The edges are double, sometimes deep-serrated, ovate or elliptical. It has a pointed tip and narrows towards the pedicel. The veins on the underside of the leaf are clearly distinguished. The color of the leaf petiole is reddish-brown. Pedicels are bare. The calyx is felt-like hairy, convex and toothed. The white petals are broadly elliptical, almost twice as long as the calyx. The fruits are spherical, first red, then dark blue. It blooms in June and bears fruit in SeptemberOctober. In general, it is widespread in the Caucasus, especially in the South Caucasus. In our Autonomous Republic, around Akhura village of Sharur district, it is spread in forest bushes in Hadi Kayib and Kuzuyatan areas.

S. kusnetzovii Zinserl. is a shrub or low-growing shrub up to 5-6 $\mathrm{m}$ high, growing in the middle and upper mountain zones, oak forests, open rocky slopes at an altitude of 1200-2400 $\mathrm{m}$ above sea level. The young shoots are reddish-brown and bare. The shoots are felt-like hairy and covered with 3-4 bright scales. The leaves are broad, inverted elliptical or elliptical. The blade part of the leaf is narrowed wedge-shaped. The tip of the leaf, which is $5-8 \mathrm{~cm}$ long and $4-6.5 \mathrm{~cm}$ wide, is pointed or rarely blunt. The upper part is bare, green, and the lower part is greyish-dense felt-like hairy. The number of lateral veins on the leaf is 7-10 pairs and the edge is double-serrated. The leaf petiole is 1.9-2.1 cm long and covered with white hairs. The petals are white, rounded. It has spherical fruits $1.3 \mathrm{~cm}$ long and $1.1 \mathrm{~cm}$ wide. It is common in the Caucasus, Lebanon and Turkey. In our Autonomous Republic, it has spread in the forests around Bichanak village of Şahbuz district and Nurgut village of Ordubad district.

S. migarica Zinserl. is a shrub that grows at an altitude of $2000 \mathrm{~m}$ above sea level, 2-3 $\mathrm{m}$ above sea level. The smooth stem bark is light gray. Young branches are reddish-brown, and old branches are dark gray. The pointed shoots are 4-6 mm long, covered with 3-4 scales, are less sticky and have felt-like hair. The egg-shaped leaves are (5) 7-9 (10) cm long, (4.5) 6-7 (8) cm wide, the upper part is blunt. It has 8-10 pairs of lateral veins. The upper surface is bare or weakly hairy, except for the veins. The veins on the lower surface have dense white felt-like hair between the veins and very weak hairs on the surface of the veins. Therefore, the veins on the lower surface of the leaf are more clearly distinguished. The edge of the leaf is completely edged from the lower part, and the upper part (1/8-1/3) has teeth, the number of which is $20-25$. The leaves and flower stalks are short and white felt-like hairy. After blooming, the receptacle, which has a triangular-toothed tooth that bends downwards, has white felt-like hair on top. It has dark red fruits $1.1-1.3 \mathrm{~cm}$ long and 1.0-1.2 cm wide. Spherical fruits contain 3-4 seeds. It blooms in May-June and bears fruit in September-October. It is widespread in the Western Caucasus and Turkey. In our Autonomous Republic, it is found in a sparse forest near the village of Nurgut in the Ordubad district.

S. tamamschjanae Gabr. is a shrub or low tree 3-6 m tall found in mixed forests. It has a smooth yellowish-brown stem bark. The leaves are 2.5-9 cm long, $1.5-5 \mathrm{~cm}$ wide, ovate or elliptical, the part close to the blade is narrowed wedge-shaped. The tip of the leaf is blunt. The upper surface is dark green, bare, and the lower surface has densely gray or whitish felt-like hair. The leaf slices are deep and have small serrated edges. The number of lateral vessels is 7-9 pairs [11, 2008 p. 83-90]. It has a group of multi-flowered thyroid. The flower petiole is initially hairy and then becomes bare. The white petals are ovate. It has a broad elliptical fruit $1.2 \mathrm{~cm}$ long and $1.1 \mathrm{~cm}$ wide. Ripe fruits are light orange in color and bright. The number of light brown seeds, $0.6 \mathrm{~cm}$ long and $0.2 \mathrm{~cm}$ wide, is 3 . The taste is not too sweet, it is mouth astringent. It blooms in MayJune and bears fruit in September-October. It is generally found in the Caucasus and 
Turkey. In our Autonomous Republic, it is spread in sparse forests around Bichanak of Shahbuz district, Nurgut village of Ordubad district and Garagush mountain of Sharur district around Lizbirt [12, 2010].

In addition to literary materials, samples collected from the territories of the Nakhchivan Autonomous Republic on the basis of our research in 2019-2020 and kept in the herbarium of the Institute of Bioresources of the Nakhchivan Branch of ANAS were used in the study of species belonging to the genus Sorbus L. in the flora of the Nakhchivan Autonomous Republic.

Conclusion. During the analysis of the species belonging to the genus Sorbus L., it was determined that the fruits, roots and stems of these plants are of great importance. They less demand the soil and have a decorative appearance. Can be used for landscaping gardens and alleys. It can also be used in beekeeping as a honey plant [17, 2014]. It attracts insects with its colorful flowers.

The wood of this plant is used in the preparation of furniture and musical instruments. Its fruit is used both as food and in the preparation of jam, compote, syrup and coffee. The fruit of Sorbus aucuparia L. species belonging to this genus is used as a mild agent in the treatment of various diseases: salt accumulation, osteochondrosis, rheumatism, gout, nephrolithiasis and urolithiasis, in the liver, improving metabolism, colds and gastrointestinal diseases [18, 2012].

In general, most of the species included in the genus Sorbus L. are considered one of the rare plants of Azerbaijan. One of the rare species, Sorbus aucuparia L. has been included in the "Red Book" of Azerbaijan. Due to the decline of the areal of S. caucasica Zinserl, S. kusnetzovii Zinserl., S. subfusca (Ledeb.) Boiss, S. persica Hedl, S. luristanica (Bornm.) Schönbeck-Temes species belonging to the genus Sorbus L. in Azerbaijan, it is necessary to include them in the "Red Book" of Azerbaijan.

\section{REFERENCES:}

1. Asbaganov S. V. Biological bases of the introduction of mountain ash (Sorbus L.) in western Siberia. Novosibirsk, 2014. 235 p.

2. Asgarov A.M. Higher plants of Azerbaijan (Abstract of the flora of Azerbaijan). Vol. 2. Baku: Elm, 2006, 284 p.

3. Flora of Azerbaijan. Baku: From the Academy of Sciences of Azerbaijan, SSR, 1954. Vol.5. 580 p.

4. Gabrielyan E.Ts. Mountain ash (Sorbus L.) of Western Asia and the Himalayas. Yerevan: Publishing house of the Academy of Sciences of the Armenian SSR. 1978. $264 \mathrm{p}$.

5. Grossgeim A.A. Flora of Azerbaijan. Baku: Azerneshr, 1936. Vol. 2. 542 p.

6. Grossheim A.A. Flora of the Caucasus. M.-L.: Iz-in of the Academy of Sciences of the USSR. 1952. V. 5.453 p.

7. Gulamova A.H. Ecobiomorphological analysis of the genus Sorbus L. distributed in the flora of the Nakhchivan Autonomous Republic. UMTEB International, Congress on Vocational Technical Sciences-x "Nakhchivan" University. P. 108-111.

8. Gulamova A.H., Distribution zones of Sorbus graeca (Spach) Hedl. species in the territory of Nakhchivan Autonomous Republic. Materials of the III International Conference of Young Researchers. Baku : BEU, 2019. P. 240-242.

9. Gulamova A.H. Biodiversity and importance in medicine of the S. aucuparia species belonging to the genus Sorbus L. in the Nakhchivan Autonomous Republic. Scientific Works of ASAU. 2021. № 1. P. 23-27.

10. Ibragimov A.Sh. Vegetation of the Nakhchivan Autonomous Republic and its national economic significance. Baku: Elm, 2005. 236 p.

11. Ibrahimov A.M. Systematic analysis and distribution zones of Sorbus (Sorbus L.) species in the flora of the Nakhchivan Autonomous Republic. ANAS Nakhchivan Branch News. Natural and technical sciences series. 2008. № 4. P. 94-97. 
12. Ibrahimov A.M. Natural resources and perspectives of use of Sorbus L. species in the territory of Nakhchivan Autonomous Republic. ANAS Nakhchivan Branch, News. Natural and technical sciences series. 2010. № 4. P. 80-84.

13. Mammadov M.S., Asadov K.S., Mammadov F.M. Dendrology. Baku: Azerbaijan Encyclopedia Publishing and Polygraphy Association, 2000. 388 p.

14. Prilipko L.I. Vegetative relations in the Nakhichevan ASSR. Baku: Iz-in AzFAN, 1939. V. 7. $196 \mathrm{p}$.

15. Seyidova H., Gulamova A. Research status of the genus Sorbus L. distributed in the flora of the Nakhchivan Autonomous Republic. News of Nakhchivan Branch of ANAS. Natural and technical sciences series. 2019. № 2. P. 150-154.

16. Talibov T.H. Flora biodiversity of Nakhchivan AR and protection of its rare species (On the cormobionta). Baku: Elm, 2001. 192 p.

17. Talibov T.H., Ibrahimov A.Sh., Ibrahimov A.M., Ismayilov A.H., Alakbarov R.A., Guliyev V.B., Gurbanov A.K. Medicinal plants of the Nakhchivan Autonomous Republic. Nakhchivan : Ajami, 2014. 432 p.

18. Talibov T.H., Ibrahimov A.M., Ganbarli A. Trees and shrubs of the Rosaceae Adans. the family that produce nectar and pollen in the flora of the Nakhchivan Autonomous Republic. Nakhchivan State University. Perspectives for the development of beekeeping in the region. International scientific-practical conference. Nakhchivan, 2014. P. 58-69.

19. Talibov T.H., Ibrahimov A.M. New species of Sorbus (Sorbus L.) for the flora of the Nakhchivan Autonomous Republic. News of Azerbaijan ANAS (biological and medical sciences). 2017. Vol. 72, № 1. P. 83-90.

20. Trees and shrubs of Azerbaijan. Baku: Elm, 1970. J. 3. 323 p. 2018.

21. Tunchkol B., Aksoy N., Eminaghaoglu O. Sorbus L. (Rowanberries). Ankara, 